\title{
Education in Cardiovascular Health in Older Group: Experience Report
}

\begin{abstract}
Belarmino Santos de Sousa Júnior ${ }^{1}$, Fernando Hiago da Silva Duarte ${ }^{2}$, Ana Elza Oliveira de Mendonça ${ }^{3}$, Tatiana Maria Nóbrega Elias ${ }^{4}$, Cíntia de Carvalho Silva ${ }^{5}$, Richardson Augusto Rosendo da Silva ${ }^{3}$, Raysa da Silva Dantas ${ }^{6}$, Débora Lenise da Silva Felix ${ }^{6}$, Alana EloahCamara Alves ${ }^{6}$, Sônia Maria da Silva ${ }^{7}$
\end{abstract}

\section{Abstract}

Introduction: Together with the population aging, the number of the vulnerable elderly cardiovascular disease also increases. With this, it is necessary to adopt health education practices to intervene in the prevention of these diseases.

Objective: To report the experience in the development of educational practices focused on the cardiovascular health of the elderly population.

Methods: This is a descriptive study of experience report type with nursing students belonging to a private university in the Northeast of Brazil, during the supervised training.

Results: The activities were dynamics, in conversations circles through instruments such as overhead projector and posters. Illustrative materials (folders) were available to participants for better fixation of the content covered. The educational activities had the active participation of elderly people who were able to share their experiences and questions.

Conclusion: It was observed that to start educational activities, the elderly people had some knowledge gaps in the topic covered, mitigated as the actions were happening, a fact that was perceived through conversation circles and dynamics at the end of each activity. Educational activities are of great relevance to nursing practice aimed at promoting health, preventing disease and improving the quality of life.
1 Nursing Student at the Potiguar University (UnP). Natal, RN/Brazil.

2 Nurse. Master degree student of the Federal University of Rio Grande do Norte (UFRN).Natal, RN/Brazil.

3 Nurse. Ph.D. in Nursing by the Federal University of Rio Grande do Norte (UFRN). Natal, RN/Brazil.

4 Nurse. Master degree in Nursing by the Federal University of Rio Grande do Norte (UFRN). Natal, RN/Brazil.

5 Nurse. Master degree in Nursing by the University of Pernambuco (UPE). Caruaru - PE/Brazil.

6 Nurse. Federal University of Rio Grande do Norte (UFRN). Natal, RN/Brazil.

7 Nursing Student of the University Center of Rio Grande do Norte (UNIRN).Natal, RN/Brazil.

Contact information:

\section{Belarmino Santos de Sousa Júnior}

झ sousajunyor@gmail.com

\section{Keywords}

Nursing; Health Education; Health of the Elderly. 


\section{Introduction}

The aging process of the population has been highlighted worldwide and brings new challenges for political, economic, demographic and socio-cultural issues. It is estimated about two billion people aged 60 years old or more in the world by 2050, most of them living in developing countries, which refers to the global aging phenomenon [1]

The growing number of older people is a reality in Brazil, resulting from population aging due to change in the profile of morbidity and mortality $[2,3]$. Thus, the Brazilian Institute of Geography and Statistics (IBGE) confirms this statement, revealing the increase elderly population number in 2010, while the number of people up to 25 years old had lower representation in the total population in Brazil [4].

This population is more vulnerable to developing chronic diseases. In the public health area, it is aimed to reduce the impact of these diseases, mostly through health promotion, prevention, and reduction of complications [5]. According to the World Health Organization (WHO), the Non-communicable chronic diseases (CNCD) are highlighted where the most prevalent are cardiovascular, respiratory diseases, diabetes mellitus and cancer, and the cardiovascular disease are globally responsible for $30 \%$ of total deaths [6].

Old age is a crucial factor for such diseases development in the individual, apparently due to the interaction between predisposing genetic factors, modifiable risk factors such as drinking excessive alcohol, smoking, and consumption of unhealthy foods, sedentary lifestyle, and obesity [7].

Thus, for a better quality aimed at this population, low-cost and considered simple actions can be implemented to health education, and the professional nurse is responsible for one of the main health action: the education action as a fundamental method for enabling care [8]. When grown in groups, the educational activities demonstrate the interaction between the participants, in which the elderly is shown free to share experiences, ques- tions, and learning, and to search for self-awareness and reflection on the health-disease process in individual and collective level, promoting the personal and social development of the participants [9].

These groups may become relevant tools for health promotion and education $[10,11]$. The practice of health education has always been highlighted in nursing daily work. However, it needs to be seen as an additional component to the activities developed in clinical practice [12].

In this sense, it becomes important the achievement of health education practices aimed at elderly people, justified by the nursing activities for this population, and acting to perform education on topics related to cardiovascular health.

Based on these and the relevance of this study topic, the objective was to report the experience in the development of educational practices for cardiovascular health facing the elderly population.

\section{Methods}

This is a descriptive study of the type of the experience report type by nursing students of a private university located in the Northeast Region of Brazil during the supervised training II. The activities were developed in an elderly homecare of the city with educational practices for the elderly, in the period from May to July 2016.

The study took place in one of the Long Term institutions (ILPES) of the city of Natal; Rio Grande do Norte. The ILPES are institutions that incorporate Home Care Services $(\mathrm{HC})$ with the support of the Best Home program of the federal government. These elderly people are assisted by a health team linked to such programs where they receive home care once a week by a multidisciplinary team. The institution also has the presence of students in the health area such as psychology, nursing, nutrition, physical education, physiotherapy, and dentistry, participating in several activities, such as forró groups, physical activities, recreational activities and embroidery. 
The proposal on the topic was chosen based on reports from earlier training where in most cases, there was racking on the health problems of that population in which cardiovascular disease was first on the list. Also, they also considered the reports of health professionals who assisted that population. After this, a schedule of educational activities was created, becoming available to those responsible for ILPES and the elderly. The sample consisted of elderly men and women, aged 65 or older, present on the appointed day to carry out the actions voluntarily.

The following topics related to cardiovascular health were addressed: physical activity; eating habits including salt intake; obesity; alcohol consumption and smoking. Each topic was presented in a clear and objective way, focusing on the damage when some of them are included in the lifestyle habits and health benefits if adopted measures and healthy styles.

In the days of the actions, after being welcomed, the elderly were sent to the auditorium of the institution and sequentially positioned in circles to establish good communication between all using the method of conversation circle. The first activity began with a dynamic presentation for the whole group to meet. There were probing actions performed through a conversation before performing the actions briefly to investigate the knowledge on the subject that would be discussed. The actions took place in an informal and relaxed way, demonstrative, explanatory and dynamically allowing greater comfort for the spectators, addressing the central theme for that day using explanatory posters with illustrative pictures, charts, memory games, to facilitate actions because some older people were illiterate.

\section{Results and Discussion}

There were five educational moments with the elderly in predetermined days. In each action, concern about the theme addressed and how the elderly felt happy with the presence of students was perceived, since most of the time they remained alone. In addition to learning more about health adding to their everyday life, activities and relaxation allow interaction between them. Descriptions of activities are listed in Table 1, which describes the number of meetings ( $n)$, some participants $(P)$, objectives and description of the activities.

The educational actions permeated were based on a clear and accessible language, aiming to interrelate the content delivered to the everyday life of the elderly. It is worth noting the importance of the survey to ascertain the level of education of the participants to adapt the language and the appropriate level of content to be covered during the actions that guide the understanding of the patients contributing to the population's access health-related

Table 1. Description of the objectives and development of educational activities. Natal/RN, 2016.

\begin{tabular}{|c|c|c|c|}
\hline n & $\mathbf{P}$ & Objective & Description \\
\hline 1 & 22 & $\begin{array}{l}\text { To demonstrate } \\
\text { basic techniques } \\
\text { of stretching and } \\
\text { the importance of } \\
\text { physical activity. }\end{array}$ & $\begin{array}{l}\text { There was dynamic with blast balls that aimed to know the group. After physical activity was } \\
\text { discussed with the elderly highlighting the importance of exercising and maintaining a healthy } \\
\text { life, associated with good nutrition for a better quality of life. Illustrative images posters were } \\
\text { used, explaining the benefits of physical activity, such as improved immunity, which may } \\
\text { decrease the incidence of infection, prevention and control of certain diseases, especially } \\
\text { cardiovascular; it strengthens muscles and maintain body weight; increased physical capacity, } \\
\text { flexibility and balance and reducing the risk of falls. There were also exercise and stretching } \\
\text { demonstrated using materials easily accessible, such as brooms and chairs, plastic bottles, } \\
\text { increasing the importance of physical exercise, especially in the elderly. It was reported to the } \\
\text { participants the importance of consulting with a medical professional before performing any } \\
\text { physical activity and intake of water before, during and after activities. }\end{array}$ \\
\hline
\end{tabular}




\section{n $\mathbf{P} \quad$ Objective}

228 To describe the benefits of healthy eating as well as pointing out the risks of a poor diet. combination of a poor diet, sedentary lifestyle and obesity and their influence on cardiovascular problems

432 To expose the risks and consequences of consumption of alcohol and the damage to cardiovascular health.

532 To expose the risks and consequences in smoking practice.
It was requested that each elderly was giving his opinion on the subject, very simply and according to what they knew. Curiosities and questions were answered arisen with the group during the action. When asked about the concept of healthy eating, they interlocked to a good quality of life. After that, there was a presentation on the benefits of healthy eating and what the consequences of a poor diet as well as the importance of conducting all meals (breakfast, lunch, healthy snacks and dinner) and feeding every 3 hours. The time took advantage to talk about the intake of salt teaching them to produce herbal salt, avoiding the consumption of processed foods with high salt content (sodium), drink 6 to 8 glasses (2 liters) of water per day. For better fixation of the contents administered during the action, there were illustrative brochures distributed with all the subject matter.

After welcoming the participants, the demonstration of the food pyramid, food groups and the benefits of each group and the risk of an impulsive power were shown. A game with pictures of the food which represented the good and the bad food allowed building a relaxed learning. It was noted that they were aware of the importance of good nutrition and reported the difficulty in adopting these habits. The incentive for the adoption of a healthy diet to prevent obesity contributes to the prevention of diseases, especially cardiovascular. Thus, the sedentary lifestyle that linked to a poor diet can bring health risks, but also corroborate overweight, that combined they can cause serious cardiovascular problems.

It was started by a conversation to expose their thoughts on alcohol which was possible to realize their understanding of the subject of this act. However, when asked what would be the harm to health about alcohol consumption they could not answer. Some reported that they were drinking alcohol and who were influenced by friends. They reported some problems occurred because of alcohol consumption, such as liver and lung problems. Photos with posters were used which showed the consequences of the consumption of alcohol on the human body.

Smoking habit was practiced by most participants. A quantitative elderly already said they smoked in life while a small number were active smokers. Former smokers reported feeling better after the abolition of cigarette and did not want to go back to smoking. The internet pictures were displayed on posters that revealed the practical consequences of smoking on the human body, as well as comparisons between organs of smokers and nonsmokers. The substances contained in cigarette and diseases caused by smoking were presented, whether active or passive smoking. It was sought to demonstrate that smoking does not bring health benefits, and encourage changing the habit to those who smoke. issues, the adherence and awareness focusing on prevention of diseases and injuries [12].

The best way to reach the people to change their harmful habits to healthy habits is through health education, which becomes essential. Thus, it is necessary commitment and commitment to such actions, so there is a change in people's lifestyle, even though they are long-term practices [13].

According to the World Health Organization (WHO), 30\% of all deaths in the world are related to cardiovascular problems. Hypertension is a major risk factor contributing to the rates of cardiovascu- lar morbidity and mortality, considered one of the major health public diseases in Brazil [6].

The importance of a regular physical activity is one aspect that corroborates a healthy lifestyle, which helps in the prevention of diseases, especially cardiovascular diseases. However, for this practice becomes effective, both to reduce blood pressure as weight reduction, it needs to be appropriate gradually over three to five times a week for a minimum duration of 30 minutes [14].

In this sense, regular physical exercise interferes with mechanisms that interact with each other and 
depend on factors such as age, ethnicity, genetics, the body undergoes adjustments and cardiovascular adaptations, assisting in control of dyslipidemia and blood pressure for example [15].

Inadequate food intake in the excessive salt intake can be highlighted as a powerful trigger of cardiovascular diseases, particularly hypertension. Although it is a condition that depends on other factors, the probability of developing hypertension increases considerably [16]. Thus, assuming that cardiovascular diseases are among the leading causes of death in adults, appropriate control of the consumer is required to sodium, which should not exceed $5 \mathrm{~g}$ sodium equivalent to $2 \mathrm{~g}$ of salt. Such consumption must be combined with a good fluid intake, a healthy diet, adequate intake of potassium and combating excessive alcohol consumption and smoking and physical inactivity [17].

Another important result stands out for the high prevalence of overweight because it is associated with chronic diseases, increasing the mortality rate and raising public health spending $[18,19]$. The overweight association with the presence of diabetes mellitus and hypertension is evidenced in some studies. According to Scherer and Vieira, the outbreak of diseases such as diabetes mellitus and hypertension is associated with obesity [20].

Social and cultural factors may be associated with alcoholism in elderly men since the habit was not observed in women of the same age. Thus, health professionals should focus on this issue addressing alcohol's relationship to cardiovascular diseases aggregated to full attention to human health. During the home visits, the nurse in the approach to the family should pay attention to signs that demonstrate the use of alcohol by any of the members. In some situations, when observed more severe intake, the professional must refer the elderly to treatment for specific groups [21].

Related to smoking, studies show that the incidence of mortality in the elderly can be enhanced with the use of tobacco, and other damage to health. Smoking is constituted as a significant risk factor for the onset of cardiovascular disease including when associated with high blood pressure that can lead to acute myocardial infarction [15].

Interventions inherent in smoking cessation treatment consist in encouraging an individual behavioral change considering a multi and interprofessional approach, and the smoker is assessed, supported, monitored and treated by this team, ensuring effective treatment [22].

In this context, preventive measures become relevant to an early abandonment of addiction, informing the harmful effects of smoking through health education, such as increased blood pressure, cancers, lung problems and other diseases and contributing to adherence to a better quality of life $[21,22]$.

Thus, health education is seen as an important strategy, since it makes and empowers individuals as autonomous decision-making to search for a better standard of health and well-being, through reflection - action - reflection [23]. This construction of knowledge among health promotion practices reveals a process that needs to be done continuously, either in individual or collective focus, with the participation of family and social groups [24]. However, referring to the nursing professional, it is important that he has the profile to work with health education, to take his teacher's position as something inherent to his profession, conducting educational activities continuously as a health promotion tool and prevention of diseases of patients, especially in the elderly [25].

\section{Conclusions}

From the development of this study, it was observed that health education contributed to the improvement in the lifestyle of the elderly population, as regards the prevention and control of cardiovascular diseases, despite the existence of resistance and difficulties presented by the elderly regarding the 
changes in lifestyle. The purpose of the action was to guide them about the risks and consequences of the factors that trigger cardiovascular diseases, which allowed the development of knowledge concerning the issues addressed. It was noted that to start educational activities, older people had some knowledge gaps in the topic covered, being mitigated as the actions were happening, a fact that was perceived through conversation circles and dynamics made at the end of each activity.

It was also identified a low turnout of older people in activities, which happened for personal reasons such as examinations, medical consultations, which made them somewhat prejudiced regarding the acquisition of new knowledge.

Thus, they were motivated and intended for improving and changing daily habits as they were obtained information on activities, and the number of participants has been increasing every meeting. Some changes in the summer of life of participants were physical exercise, reduced salt intake in food and adopting a healthy diet. Such educational activities are of great relevance to nursing practice aimed at health promotion and disease prevention and the pursuit of quality of life.

\section{References}

1. Brasil. Secretaria de Atenção à Saúde. Departamento de Atenção Básica. Envelhecimento e Saúde da Pessoa Idosa. Brasília: Ministério da Saúde. 2013 [cited at 08 de jul de 2016]. Available from: http://bvsms.saude.gov.br/bvs/publicacoes /abcad19.pdf

2. Oliveira $A B P L$, Menezes PMR. Representações de fragilidade para idosos no contexto da Estratégia Saúde da Família. Texto Contexto Enferm [Internet]. 2011 [cited at 22 jul 2016]; 20(2):301-09. Available from: http://www.scielo.br/pdf/tce/ v20n2/a12v20n2.pdf

3. Torres JL, Dias CR, Ferreira RF, Macinko J, Costa LFM. Functional performance and social relations among the elderly in Greater Metropolitan Belo Horizonte, Minas Gerais State, Brazil: a population-based epidemiological study. Cad. Saúde Pública [Internet] 2014 [cited at 12 jul 2016];30(5):1018-28. Available from: http://www.scielo.br/pdf/csp/v30n5/0102-311Xcsp-30-5-1018.pdf
4. Instituto Brasileiro de Geografia e Estatística- IBGE [Internet]. 2010 [cited at 16 jul 2016]. A Available from: http://censo2010. ibge.gov. br/noticiascenso? view $=$ noticia\&id=3\&idnoticia $=17$ 22\&busca $=1 \& \mathrm{t}=$ dados-preliminares-censo2010-járevelammudancas-piramide-etaria-brasileira

5. Veras RP. Um modelo em que todos ganham: mudar e inovar, desafios para o enfretamento das doenças crônicas entre idosos. Acta Scientiarum [Internet]. 2012 [cited at 21 ago 2016]; 34(1):3-8. Available from: http://periodicos.uem.br/ojs/index. php/ActaSciHumanSocSci/article/view/16181/pdf

6. Oshiro ML, Ferreira JS, Oshiro E. Hipertensão Arterial em trabalhadores da estratégia saúde da família. Revista Brasileira de Ciências da Saúde [Internet]. 2013 [cited at 07 ago 2016]; 11(36):20-8. Available from: http://seer.uscs.edu.br/index.php/ revista ciencias saude/article/view/1786/1404

7. Magalhães BS, Ibiapina DF, Carvalho DR. Avaliação nutricional e prevalência de diabetes e hipertensão em idosos. $\mathrm{R}$ Interd [Internet]. 2014 [cited at 05 jun 2016]; 7(4):131-8. Available from: $\quad$ http://revistainterdisciplinar.uninovafapi.edu.br/index. php/revinter/article/view/476/pdf 167

8. Ritter CB, Aires M, Rotolli A, Santos JLG. Grupo como tecnologia assistencial para o trabalho em enfermagem na saúde coletiva. Saúde \& Transformação Social / Health \& Social Change [Internet]. 2014 [citet at 10 jul 2016];5(3):83-90. Available from: http://www.redalyc.org/articulo.oa?id=265335335012

9. Souza MCMR, Horta NC. Enfermagem em saúde coletiva: teoria e prática. Rio de Janeiro: Guanabara Koogan; 2013.

10. Gurgel MGI, Alves MDS, Moura ERF, Pinheiro PNC, Rêgo RMV, Passos MLL. Promoção da saúde no contexto da estratégia saúde da família: concepções e práticas da enfermeira. Esc Anna Nery [Internet]. 2013 [cited at 22 jul 2016];15(3):610-5. Available from: http://www.scielo.br/pdf/ean/v15n3/a24v15n3.pdf

11. Ferreira Neto JL, Kind L. Práticas grupais como dispositivo na promoção da saúde. Physis [Internet]. 2012 [cited at 20 jun 2016];20(4):1119-42. Available from: http://www.scielo.br/pdf/ physis/v20n4/a04v20n4.pdf

12. Valente GSC, Lindolpho MC, Mello LP, Gomes HF, Sás SPC. O perfil das mulheres participantes de um programa de extensão de enfermagem. J res fundam care online [Internet]. 2013 [cited at 2014 Nov 23];5(4):606-13. Available from: http://www.seer. unirio.br/index.php/cuidadofundamental/article/viewFile/2130/ pdf 942

13. Ribeiro MILC, Pedrão LJ. Relacionamento Interpessoal no nível médio de Enfermagem. RevBrasEnferm [Internet]. 2015 [cited at 24 jun 2016];58(3):311-5. Available from: http://www.scielo.br/ pdf/reben/v58n3/a11v58n3.pdf 
14. V Diretrizes Brasileiras de Hipertensão Arterial. ArqBrasCardiol [Internet]. 2013 [cited at 20 jun 2016];89(3):e24-e79. Available from: http://www.scielo.br/pdf/abc/v89n3/a12v89n3.pdf

15. Sociedade Brasileira de Cardiologia, Sociedade Brasileira de Hipertensão, Sociedade Brasileira de Nefrologia. VII Diretrizes Brasileiras de Hipertensão. ArqBrasCardiol [Internet]. 2012 [cited at 07 ago 2016];95(1):1-51. Available from: http://www.scielo. br/pdf/abc/v95n1s1/v95n1s1.pdf

16. Barros E, Manfro RC, Thomé FS, Gonçalves LF. Nefrologia rotinas, diagnóstico e tratamentos, 9rd ed. Porto Alegre: Artmed. 2013; p.242-65.

17. Molina MCB, Cunha RS, Herkenhoff LF, Mill JG. Hipertensão arterial e consumo de sal em população urbana. Rev Saúde Pública [Internet]. 2013 [cited at 14 ago 2016];37(6):743-50. Available from: http://www.scielo.br/pdf/rsp/v37n6/18017.pdf

18. Visscher TLS, Seidell JC, Menotti A, Blackburn H, Nissinen A, Feskens EJM, et al. Underweight and overweight in relation to mortality among men aged 40-59 and 50-69 years: the seven countries study. Am J Epidemiol [Internet]. 2012 [cited at 21 ago 2016];151(7):660-6. Available from: http://aje.oxfordjournals. org/content/151/7/660.full.pdf

19. Andrade FB, Caldas Junior AF, Kitoko PM, Batista JEM, Andrade TB. Prevalence of overweight and obesity in elderly people from Vitória-ES, Brazil. Ciên Saúde Colet [Internet]. 2012 [cited at 05ago 2016];17(3):749-56. Available from: http://www.scielo. br/pdf/csc/v17n3/v17n3a22.pdf

20. Scherer F, Vieira JC. Estado nutricional e sua associação com risco cardiovascular e síndrome metabólica em idosos. RevNutr [Internet]. 2012 [cited at 11 ago 2016];23(3):347-55. Available from: http://www.scielo.br/pdf/rn/v23n3/03.pdf

21. Diniz MA, Tavares DMS. Fatores de risco para doenças cardiovasculares em idosos de um município do interior de Minas Gerais. Texto Contexto Enferm [Internet]. 2013 [cited at 15 ago 2016]; 22(4):885-92. Available from: http://www.scielo. br/pdf/tce/v22n4/03.pdf

22. Ilha LHC, Teixeira CC, Boaz SK, Echer IC. Ações dos enfermeiros em relação ao paciente tabagista hospitalizado. Rev HCPA [Internet]. 2012 [cited at 14 ago2016];32(4):42735. Available from: http://seer.ufrgs.br/index.php/hcpa/article/ view/36136/23873
23. Santos ZMSA, Lima HP. Tecnologia educativa em saúde na prevenção da hipertensão arterial em trabalhadores: análise das mudanças no estilo de vida. Texto Contexto Enferm [Internet]. 2012 [cited at 11 ago 2016];17(1):90-7. Available from: http:// www.scielo.br/pdf/tce/v17n1/10.pdf

24. Cecagno D, Siqueira HCH, Vaz MRC. Falando sobre pesquisa, educação e saúde na enfermagem. Rev Gaúcha Enferm [Internet]. 2015 [cited at 12 ago 2016];26(2):154-60. Available from: http:// seer.ufrgs.br/index.php/RevistaGauchadeEnfermagem/article/ view/4548/2479

25. Araújo VS, Guerra CS, Moraes MN, Braga LS, Silva JB, Dias MD. Nexos e desafios da educação em saúde para idosos na atenção básica. J Nurs UFPE on line [Internet]. 2013 [cited at 2015 Mar 01];7(5):1311-8. Available from: http://www.revista.ufpe. br/revistaenfermagem/index.php/revista/article/view/3797/ pdf 2489
Publish in International Archives of Medicine

International Archives of Medicine is an open access journal publishing articles encompassing all aspects of medical science and clinical practice. IAM is considered a megajournal with independent sections on all areas of medicine. IAM is a really international journal with authors and board members from all around the world. The journal is widely indexed and classified Q2 in category Medicine. 